\title{
Validitas dan Reliabilitas Data Estimasi Kadar Uranium Sektor Lembah Hitam, Kalan, Kalimantan Barat
}

\section{Validity and Reliability of Uranium Grade Estimation Data in Lembah Hitam Sector, Kalan, West Kalimantan}

\author{
Adi Gunawan Muhammad* dan Frederikus Dian Indrastomo \\ Pusat Teknologi Bahan Galian Nuklir-BATAN \\ Jl. Lebak Bulus Raya No.09, Ps.Jumat, Jakarta, Indonesia, 12440 \\ *E-mail: adigm@batan.go.id
}

Naskah diterima: 11 November 2019, direvisi: 26 November 2019, disetujui: 26 November 2019 DOI: $\underline{10.17146 / \text { eksplorium.2019.40.2.5672 }}$

\begin{abstract}
ABSTRAK
Mineralisasi uranium (U) di Sektor Lembah Hitam pada batuan metalanau dan metapelit sekistosan berasosiasi dengan mineral pirit, pirhotit, magnetit, molibdenit, turmalin, dan kuarsa. Kehadiran mineral U ditandai dengan nilai radiometri batuan yang mencapai $15.000 \mathrm{c} / \mathrm{s}$. Estimasi cepat kadar U adalah menggunakan perhitungan gamma ray hasil logging gross-count gamma lubang bor LH-01. Penelitian ini bertujuan untuk mendapatkan validitas dan reliabilitas data estimasi kadar U. Hasil estimasi kadar U logging disebandingkan dengan analisis geokimia untuk mendapatkan faktor koreksi (Fk). Analisis geokimia menggunakan metode $X$-Ray Fluorescence (XRF) pada sampel batuan terpilih di interval kedalaman yang mewakili batuan dan mineralisasi di lubang tersebut. Estimasi kadar U di kedalaman 8,80-9,81 m berdasarkan gross-count gamma ray menunjukkan nilai kadar 456 ppm eU, sementara analisis XRF menunjukkan rerata kadar 177 ppm U. Nilai faktor koreksi (Fk) yang didapatkan dari estimasi kadar di kedalaman 8,80-9,81 m adalah 0,388. Nilai tersebut menunjukkan validitas dan reliabilitas data estimasi yang digunakan rendah. Kesebandingan estimasi kadar U dipengaruhi oleh beberapa faktor, antara lain: sistem logging gross-count gamma ray, ketidaksetimbangan uranium, ukuran sampel, dan unsur radioaktif lainnya. Untuk meningkatkan validitas dan reliabilitas data estimasi, maka diperlukan penambahan sampel analisis XRF dengan mempertimbangkan lingkar dan interval kedalaman lubang bor.
\end{abstract}

Kata kunci: validitas, reliabilitas, Lembah Hitam, logging gross-count gamma ray

\begin{abstract}
Uranium $(U)$ mineralisation in Lembah Hitam Sector in metasilt and schistossic metapellite rocks was assosiated with pyrite, pyrhotite, magnetite, molibdenite, tourmaline, and quartz minerals. The existence of $U$ mineral was marked from its radiometric value reaching $15,000 \mathrm{c} / \mathrm{s}$. The faster way to estimate $U$ grade is using gamma-ray values calculation from gross-count gamma logging at borehole LH-01. The research is aimed to obtain the validity and reliablility of $U$ grade estimating data. The logging estimation result then compared with geochemical analysis to obtain the correction factor $(F k)$. Geochemical analysis is using X-Ray Fluorescence $(X R F)$ method on selected rock samples represent rock and mineralisastion depth interval inside the borehole. The result of uranium grade estimation using gross-count gamma ray calculation in depth $8.80-9.81 \mathrm{~m}$ is $456 \mathrm{eU}$ while based on XRF analysis, the result is $177 \mathrm{ppm} U$. The correction factor $(F k)$, obtained from grade estimation at 8.80-9.81 $\mathrm{m}$ depth is 0.388 . The value indicates that the validity and reliability estimation data is low. Ratio of $U$ grade estimation depends on some factors, like gross-count gamma ray logging system; uranium disequilibrium, sampels size; and other radioactive elements. In order to increase the validity and reliability estimation data, XRF analysis samples should be added by considering the borhole diameter and depth interval.
\end{abstract}

Keywords: validity, reliablility, Lembah Hitam, gross-count gamma ray logging 


\section{PENDAHULUAN}

Mineralisasi uranium (U) di Sektor Lembah Hitam dijumpai dalam batuan metalanau dan metapelit sekistosan, dengan arah umum mineralisasi timur-barat, $\pm 70^{\circ}$ miring ke utara sejajar S1. Secara regional, Sektor Lembah Hitam termasuk dalam jalur Pegunungan Schwaner dan merupakan bagian atas dari Stratigrafi Cekungan Kalan. Litologi yang dijumpai di sektor ini terdiri dari metapelit, metapelit jeronang, metabatulanau, dan metaampelit. Lapisan pembawa uranium di Sektor Lembah Hitam adalah batuan metabatulanau dan metapelit skistosan yang berkedudukan $\mathrm{N} 265^{\circ} \mathrm{E} / 60^{\circ}$ S. Lapisan pembawa uranium tersebut berdimensi vertikal $\pm 400 \mathrm{~m}$ dan horizontal $80-100 \mathrm{~m}$. Pemineralan berada di breksi sesar dan kekar dengan arah $\mathrm{N} 280^{\circ} \mathrm{E} / 60^{\circ}-70^{\circ} \mathrm{NE}$, relatif sejajar dengan sekistositas berasosiasi dengan pirit, pirhotit, magnetit, molibdenit, turmalin, dan kuarsa dengan nilai radiometri mencapai $15.000 \mathrm{c} / \mathrm{s}$ [1]. Pada tahun 2014 telah dilakukan pengeboran evaluasi yaitu LH-01 dan telah dilakukan logging dengan grosscount gamma ray untuk mengetahui penerusan pola penyebaran pemineralan mineralisasi $U$ dan estimasi sumberdaya. Hal pertama yang dilakukan dalam estimasi sumber daya adalah mengestimasi kadar secara kuantitatif menggunakan gross-count gamma ray. Penaksiran kadar U di eksplorasi uranium dengan menggunakan gross-count gamma ray sudah sangat umum dilakukan karena relatif cepat, akurat dan jauh lebih murah dibandingkan dengan metoda yang lain. Namun demikian, penaksiran ini memerlukan asumsi-asumsi dan hal ini sering kali memberikan hasil penaksiran yang berbeda dengan hasil penentuan kadar secara laboratorium atau geokimia. Berdasarkan hal ini maka perlu dilakukan uji validitas dan reliabilitas hasil penaksiran kadar menggunakan gross-count gamma ray dengan membandingkan hasil penentuan kadar U secara geokimia.

Selama ini, penentuan kadar mineralisasi menggunakan logging gross-count gamma ray masih belum divalidasi dengan data laboratorium atau geokimia. Radiasi gamma yang tercatat oleh sistem logging gross-count gamma ray terutama berasal dari peluruhan produk ${ }^{238} \mathrm{U}$. Fakta penting yang harus diingat dalam penentuan keterdapatan mineralisasi uranium menggunakan log gross-count gamma ray adalah peluruhan uranium tidak memancarkan sinar gamma. Uranium hanya memancarkan radiasi alfa $(\alpha)$. Sebagian besar gamma ray yang tercatat oleh sistem logging gross-count gamma ray berasal dari produk turunan uranium, antara lain ${ }^{214} \mathrm{~Pb}$ dan ${ }^{214} \mathrm{Bi}$ yang merupakan produk turunan ke-8 dan 9 dalam seri peluruhan ${ }^{238} \mathrm{U}[2]$ (Gambar 1).

Penentuan kadar menggunakan logging berlaku asumsi bahwa mineralisasi uranium harus dalam kondisi equilibrium atau setimbang sehingga ada korelasi langsung antara kelimpahan produk turunan hasil peluruhan dengan material induknya, dalam hal ini ${ }^{238} \mathrm{U}$. Selain itu, unsur radioaktif lain seperti torium (Th) dan kalium (K) tidak berkontribusi secara signifikan terhadap laju pencacahan. Kondisi semacam ini biasanya dicirikan dengan adanya kesamaan hasil antara kadar ekivalen U (eU), hasil estimasi kadar U menggunakan gross-count gamma ray, dengan kadar $\mathrm{U}$ hasil analisis geokimia. Dengan membandingkan penentuan kadar dari pengukuran radioaktivitas dengan analisis kimia uranium serta mempelajari pola-polanya, maka hasilnya dapat digunakan sebagai petunjuk awal untuk memahami sejarah geokimia sampel deposit $\mathrm{U}$, khususnya di Sektor Lembah Hitam. Namun, 
informasi ini belum cukup untuk menafsirkan kesetimbangan atau ketidaksetimbangan dalam sampel atau deposit U yang ditemukan di Sektor Lembah Hitam.

Penelitian ini bertujuan untuk mengetahui validitas dan reliabilitas data estimasi kadar $\mathrm{U}$ dengan melakukan perbandingan data hasil estimasi kadar grosscount gamma ray dengan analisis geokima XRF. Sampel yang digunakan berasal dari bor LH-01 (Gambar 2) pada interval kedalaman 8,80-9,81 m. Dengan melakukan kesebandingan, maka nilai faktor koreksi (Fk) sebagai parameter untuk validitas dan reliabilitas data estimasi kadar U di Sektor Lembah Hitam dapat diketahui.

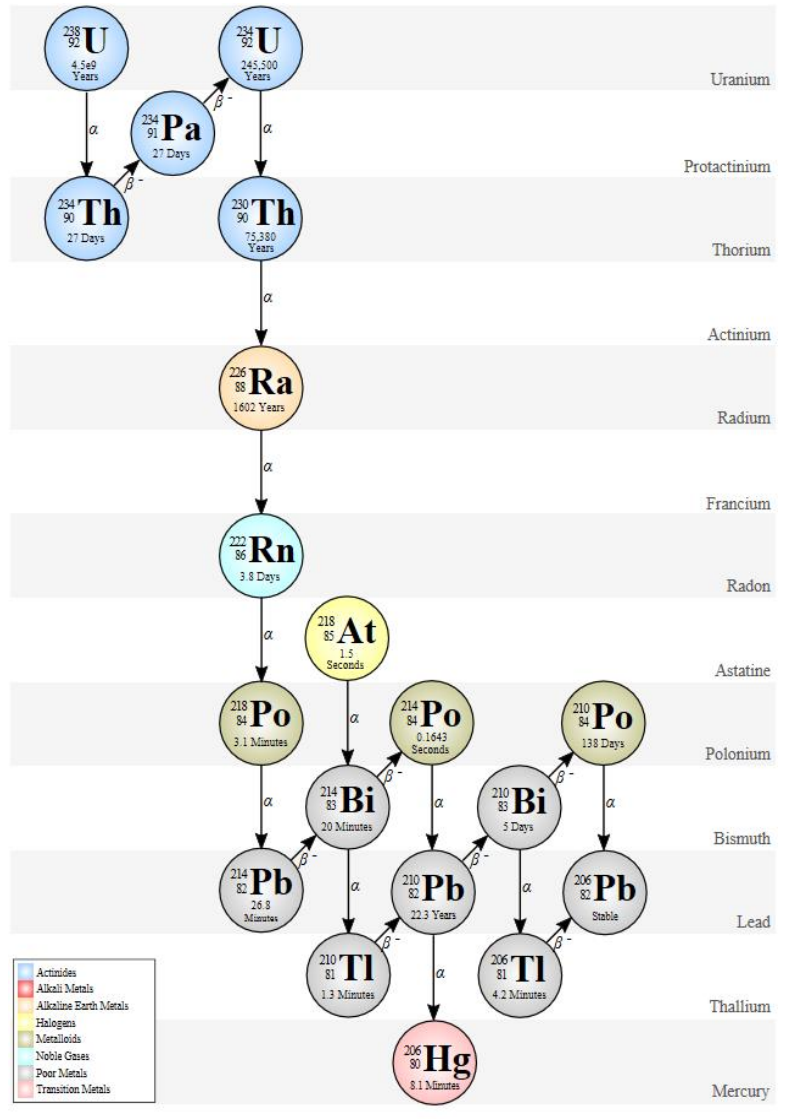

Gambar 1. Seri peluruhan radioaktif ${ }^{238} U$ (modifikasi dari [2]).

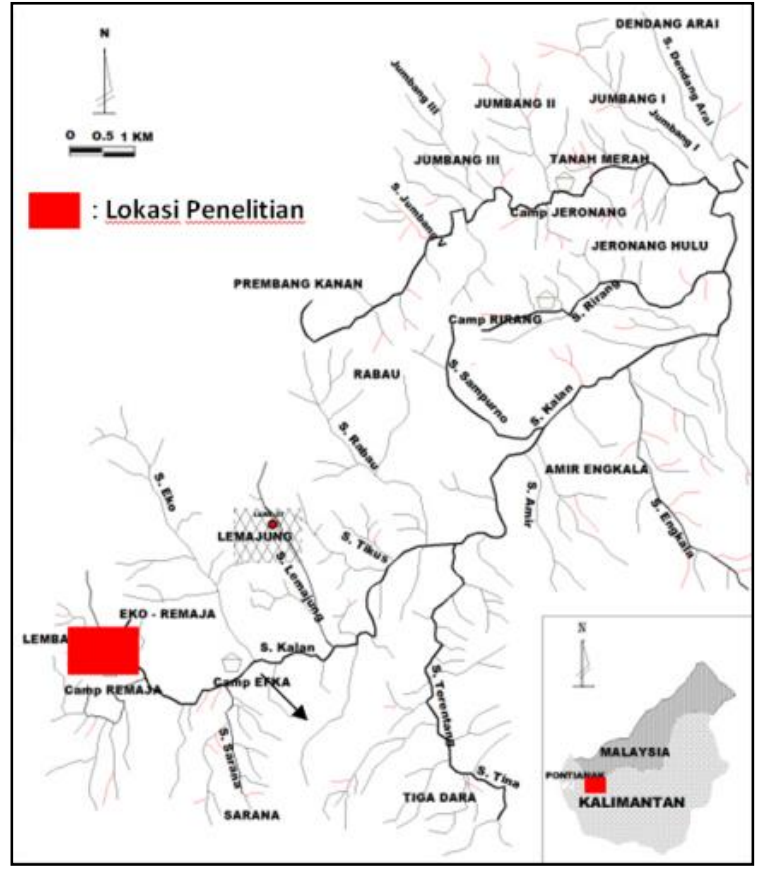

Gambar 2. Peta lokasi pengeboran LH 01 di Sektor Lembah Hitam Kalimantan Barat.

\section{GEOLOGI REGIONAL \\ Fisiografi}

Secara regional, daerah penelitian termasuk ke dalam rangkaian Pegunungan Schwanner [3] (Gambar 3). Dataran tinggi Schwanner terdiri dari pegunungan yang tertutup hutan lebat yang umumnya berkemiringan lereng lemah-sedang, mulai dari dataran rendah Melawi hingga ke bagian utara. Ketinggian maksimum kurang lebih $1.700 \mathrm{~m}$. Dataran tinggi tersebut terbentuk oleh batuan granit dan malihan yang diterobos oleh sedikit batuan sub-gunung api di barat laut, hulu sungai Sepauk. Puncak tertinggi dan lereng berkemiringan terjal umumnya terdapat di batuan malihan $[4,5]$. Sungai utama dan cabang-cabangnya cenderung mengalir berkelok dengan banyak sungai lurus yang mencerminkan retakan atau pecahan dari batuan. Cabang-cabang sungai kecil umumnya membentuk pola aliran mendaun. 


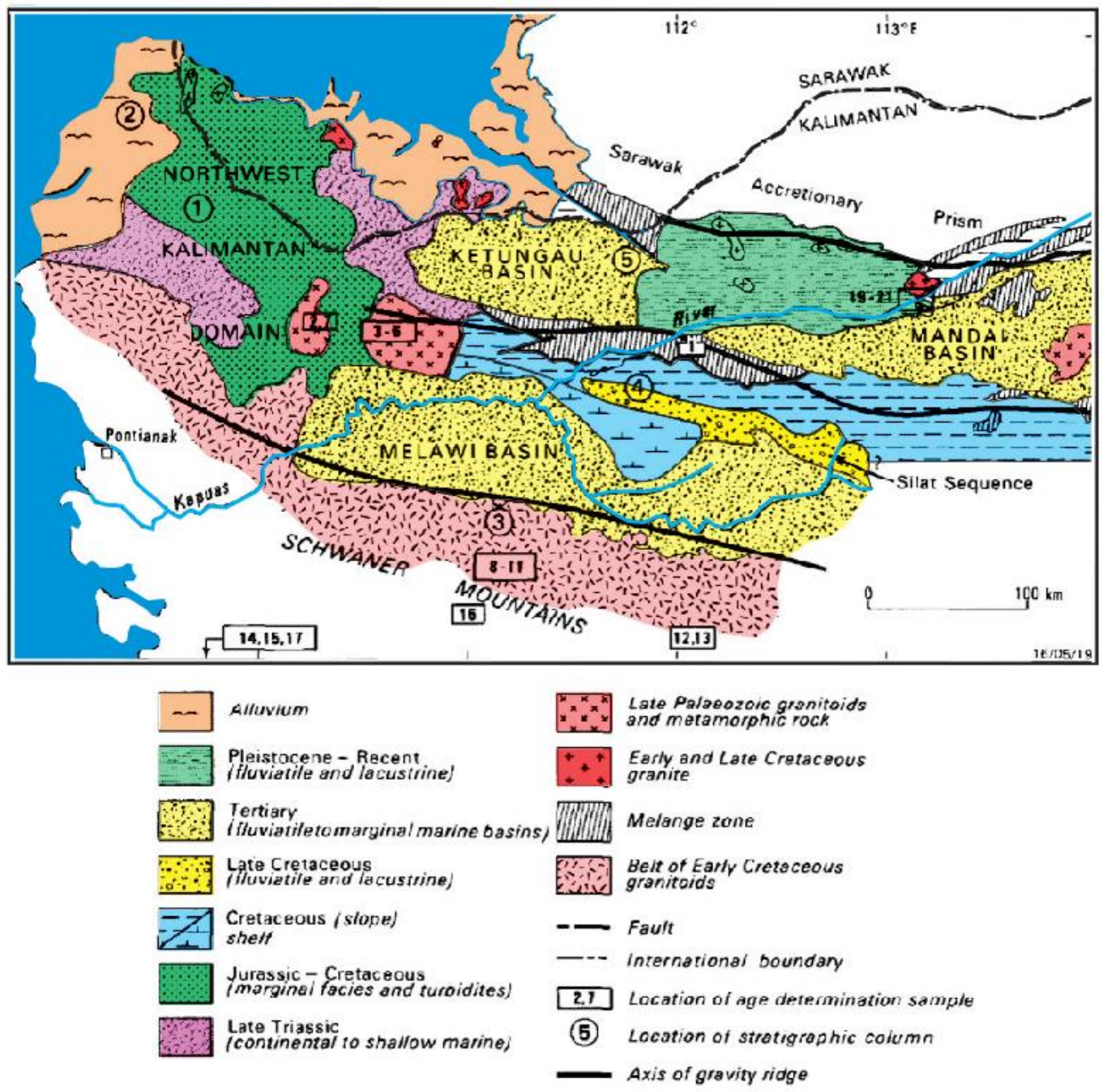

Gambar 3. Fisiografi regional Kalimantan Barat [3].

\section{Struktur Geologi}

Secara tektonik, daerah pegunungan Schwanner di bagian utara dibatasi oleh sistem sesar berarah $\mathrm{N} 100^{\circ}-110^{\circ}$ E sebagai akibat terbentuknya cekungan Melawi yang kemudian diisi oleh sedimen yang sangat tebal. Beberapa elemen struktur yang dikenali pada batuan metamorf fasies rendah adalah kelurusan $\mathrm{N} 50^{\circ} \mathrm{E}$ di daerah Kalan dan N $150^{\circ}-160^{\circ}$ E di daerah Ella Hilir. Sementara itu, di batuan metamorfik dengan fasies lebih tinggi di Laur Ella berarah $\mathrm{N} 120^{\circ}$ E. Arah $\mathrm{N} 50^{\circ} \mathrm{E}$ (Kalan Lineament) yang merupakan arah tektonik di daerah Kalan, merupakan tektonik tua yang teraktivasi kembali (Gambar 4).

Perangkap mineralisasi pada fraktur batuan sangat dipengaruhi oleh sifat plastisitas batuan. Faktor litologi sangat berperan mengontrol geometri dan urat mineralisasi sebagai respon terhadap aktivitas tektonik [6]. Pada batuan metapelit, urat mineralisasi akan berukuran tipis dan rapat mengikuti arah sekistositas, sementara pada metalanau urat mineralisasi berukuran tebal dan membentuk breksi mineralisasi mengisi rekahan-rekahan di sekitar zona sesar [7].

Gejala tektonik di Kalan dicirikan oleh 2 deformasi yaitu deformasi plastis (lipatan) 
dan deformasi brittle/getas (frakturasi dan/atau sesar), diawali dengan perlipatan dan berkembangnya sekistositas batuan pada umur Trias [1, 8]. Gejala lipatan dengan sumbu berarah $\mathrm{N} 70^{\circ}$ E menunjam $30^{\circ}$ ke timur laut, menghasilkan sekistositas dengan kemiringan $\pm 70^{\circ}$ ke utara relatif sejajar dengan sumbu lipatan. Deformasi getas pertama menyebabkan terjadinya bukaan pada unsur tektonik maupun sekistositas sebagai akibat perubahan gaya kopel berarah sinistral yang terjadi pada Jura, kemudian berubah menjadi dekstral pada Jura Akhir [9, 10]. Selanjutnya, terjadi pengendapan larutan U (uraninit, branerit) [11] yang membentuk urat-urat dan breksi mineralisasi sejajar dengan sekistositas di Jaman Kapur. Kemudian, deformasi getas kedua menghasilkan sesar dan kekar yang terisi oleh kalsit dan gypsum dengan ketebalan sentimetrik-desimetrik membentuk urat-urat (vein) yang sering memotong mineralisasi $\mathrm{U}$ tanpa menunjukkan pergeseran yang berarti.

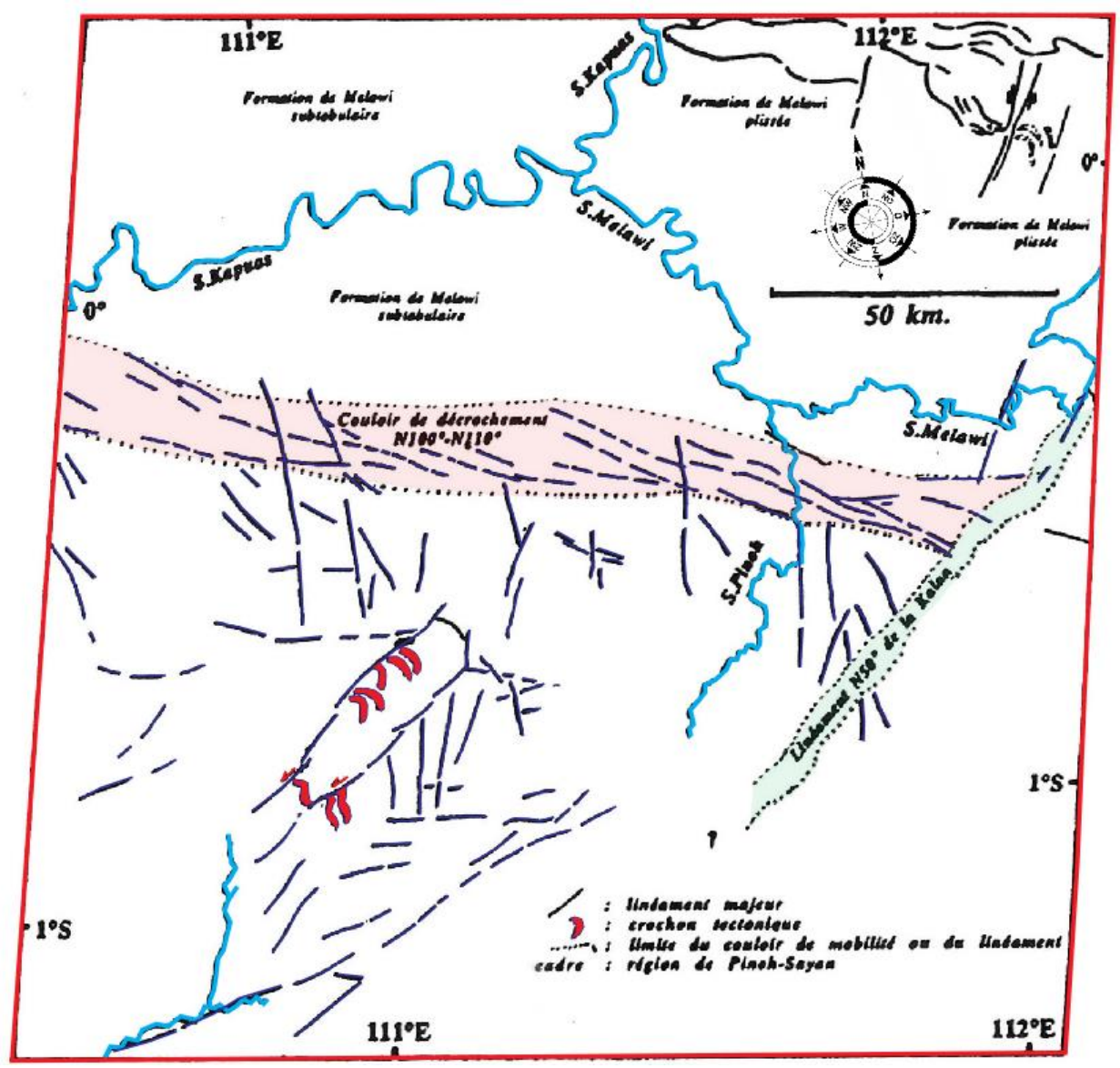

Gambar 4. Tektonik regional daerah Kalan dan sekitarnya [12].

\section{Stratigrafi}

Secara regional, Cekungan Kalan adalah cekungan sedimenter yang terdiri dari sedimen Permo-karbon berbutir kasar-halus yang mengalami metamorfosis tingkat rendah. Batuan metamorf ini dikenal sebagai batuan malihan Pinoh yang berumur
Paleozoikum [13] hingga Trias [14]. Pentarikhan U-Pb zirkon pada batuan tersebut menunjukkan protolit vulkanogenik berumur Kapur Awal yang kemudian diterobos oleh granitoid Schwaner sehingga mengalami metamorfosis [15, 16]. Metamorfosis kontak menghasilkan mineral hornfels kordierit- 
andalusit-silimanit dan hornfels andalusitsilimanit [17]. Tonalit merupakan batuan magmatik tertua di Pegunungan Schwaner [18] yang memiliki kemiripan dengan Kompleks Embuoi di Kalimantan bagian barat daya [3] dan granodiorit Jagoi di Sawarak Barat [19].

Stratigrafi Cekungan Kalan di daerah penelitian dibagi menjadi tiga seri, yaitu seri bawah (lower serie), seri tengah (intermediet serie) dan seri atas (upper serie) seperti terlihat pada Gambar 5 [12]. Seri bawah meliputi Sektor Dendang Arai, Tanah Merah, Jumbang I, Jumbang II, Jumbang III dan Prembang Kanan yang dicirikan oleh batuan berbutir kasar dengan terobosan-terobosan granit di sepanjang perlapisan. Sedangkan Sektor Rabau termasuk seri tengah (intermediate serie) yang dicirikan batuan kuarsit yang berukuran kasar-sedang. Sementara itu, Sektor Lembah Hitam, Remaja, Lemajung, Sarana, Amir Engkala dan Rirang termasuk seri atas yang dicirikan oleh perselingan batuan gunung api dan sedimen, di beberapa tempat mengandung material karbon.

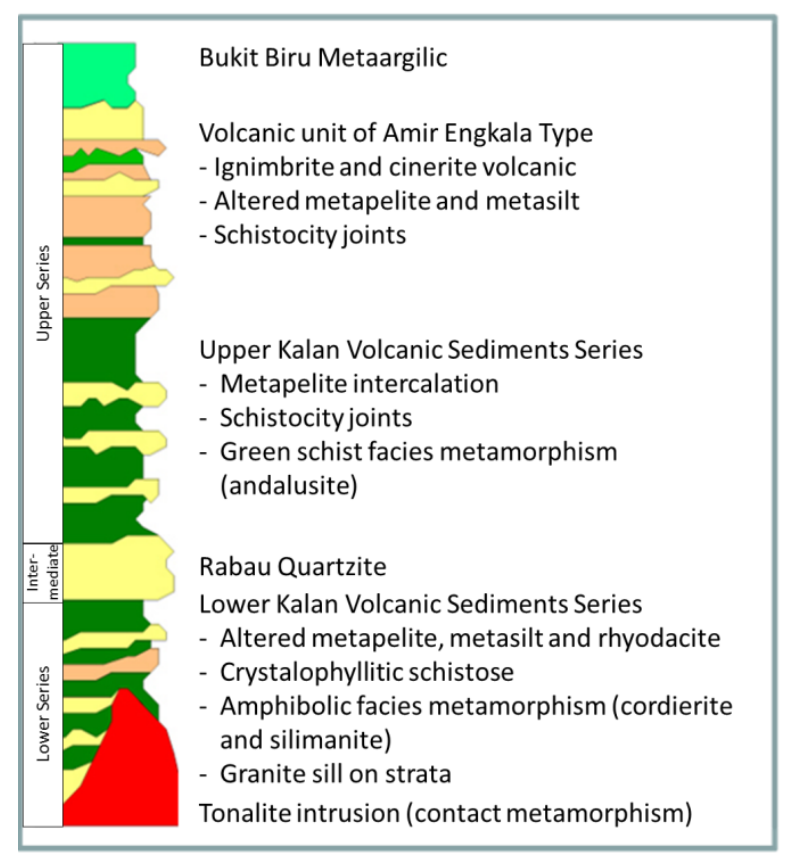

Gambar 5. Stratigrafi Cekungan Kalan [12, 20].

\section{METODOLOGI}

\section{Penentuan Kadar U dari Logging Sumur Bor}

Sampel batuan berasal dari batuan inti hasil pengeboran di lubang bor LH-01 Sektor Lemajung. Sumur lubang bor ini dilengkapi dengan data logging geofisika. Informasi di dalam logging geofisika yang digunakan adalah nilai gross-count gamma ray yang dideteksi oleh probe. Hasil log gamma ini kemudian diinterpretasi untuk mengetahui sebaran anomali uranium di dalam lubang bor. Kadar ekivalen uranium (eU) kemudian dihitung berdasarkan nilai gross-count gamma ray.

Ketidaksetimbangan (Disequilibrium) merupakan salah satu faktor terjadinya perbedaan hasil antara estimasi kadar dari logging sumur bor atau kadar ekivalen (eU) dengan data dari analisis geokimia, sehingga penaksiran kadar U menggunakan gross-count gamma ray diasumsikan bahwa uranium berada dalam keadaan setimbang (equilibrium). Equilibrium adalah kondisi ketika jumlah material induk $\left({ }^{238} \mathrm{U}\right)$ dalam batuan kesetimbangan kimianya belum terganggu sehingga jumlahnya ekivalen dengan produk peluruhannya $\left({ }^{214} \mathrm{~Pb}\right.$ dan ${ }^{214} \mathrm{Bi}$ ). Oleh karena itu, ada korelasi langsung antara kelimpahan produk turunan hasil peluruhan dengan material induknya, $\left({ }^{238} \mathrm{U}\right)$. Ketidaksetimbangan pada bijih mineral radioaktif telah menghadirkan masalah yang sulit bagi ahli geologi dan prospektor di eksplorasi uranium karena akan berpengaruh terhadap hasil perhitungan sumber daya. Besaran dan frekuensi ketidaksetimbangan umumnya telah diabaikan. Namun, saat ini pemahaman kondisi ketidaksetimbangan di lapangan dan pengukuran laboratorium telah mulai diperhatikan dan direalisasikan. 
Ada 3 teknik logging yang biasa digunakan dalam eksplorasi uranium, yaitu radioactivity logging, electrical logging dan mechanical logging. Gross-count gamma ray adalah salah satu jenis log gamma ray yang digunakan secara luas di dalam menemukan dan mengevaluasi mineralisasi uranium. Pengukuran data logging memanfaatkan radioaktivitas uranium dan produk peluruhannya. Walau demikian, uranium sendiri tidak memancarkan sinar gamma, peluruhannya dengan memancarkan partikel $\alpha$. Produk peluruhan uranium merupakan sumber sinar gamma. Unsur ${ }^{214} \mathrm{~Pb}$ dan ${ }^{214} \mathrm{Bi}$ berkontribusi besar terhadap sinar gamma yang terekam oleh sistem logging gross-count gamma ray. Prinsip dasar logging gross-count gamma ray adalah:

$$
\mathrm{G}_{\gamma} \cdot \mathrm{T}=\mathrm{k} . \mathrm{A}
$$

Simbol "A" mencerminkan area terkoreksi di kurva log gamma dalam unit cps-meter. $\mathrm{G} \gamma$ adalah rata-rata ekivalen radiometri kadar uranium dalam suatu zona mineralisasi dengan panjang " $T$ " sepanjang lubang bor. Nilai k (k-faktor) ditentukan oleh kalibrasi sistem alat dan merupakan unit ekivalen kadar uranium dibagi nilai cacahan per detik (count per second/cps) dalam satuan $\% \quad \mathrm{eU}_{3} \mathrm{O}_{8} / \mathrm{cps}$. Kadar ditentukan dengan bantuan akumulasi $\mathrm{G} \gamma$ x T, hasilnya berupa kadar dan ketebalan.

\section{Korelasi Inti Batuan dengan Log Gamma}

Sampel batuan inti yang didapatkan dari lubang bor kemudian juga diukur dengan menggunakan sintilometer SPP2NF untuk mengetahui nilai radiometrinya. Nilai radiometri yang diperoleh dalam satuan count per second (cps).

Penentuan keberadaan mineralisasi pada inti bor dilakukan dengan menggunakan alat SPP2NF dan XRF. Hasil pengukuran
SPP2NF dan XRF kemudian dikorelasi dengan data logging. Dalam penentuan ini, respon hasil pembacaan logging sumur bor pada kedalaman yang sama juga harus dipertimbangkan.

\section{Analisis Kadar U menggunakan Metode XRF}

Untuk mengetahui nilai kadar atau kadar ekivalen rata-rata uranium di dalam batuan, maka dilakukan analisis logging gross-count gamma ray dan analisis laboratorium dengan menggunakan metode X-Ray Fluorescence (XRF). Kadar ekivalen rata-rata mineralisasi U di dalam batuan dapat ditentukan dengan menggunakan prinsip dasar log gamma yaitu $\mathrm{G} \gamma \mathrm{T}=\mathrm{k}$.A. Metode ini merupakan metode kuantitatif [2] sehingga membutuhkan ketelitian tinggi dalam pengukuran dan penghitungannya. Hasil estimasi kadar dari logging sumur bor harus diverifikasi dengan metode geokimia kualitatif untuk mendapatkan faktor koreksi nilai kadar rataratanya [2]

Sampel geokimia yang digunakan adalah batuan inti bor pada interval kedalaman 8,80 9,81 m. Interval kedalaman ini ditentukan dari nilai anomali gamma ray yang terlihat pada log gamma. Nilai anomali ini kemudian dikorelasikan dengan inti bor sehingga kedalaman sampel batuan inti bor dapat ditentukan dan batuan yang terambil kemudian diukur besaran radiometrinya menggunakan SPP2NF.

Batuan inti dicuplik sebanyak setengah volumenya dengan panjang $5 \mathrm{~cm}$ sesuai dengan interval pengambilan log gamma. Jumlah sampel yang terambil adalah 11 sampel. Sampel batuan kemudian digerus hingga berukuran 200 mesh [21] dan dibuat menjadi pelet. Pelet tersebut kemudian dianalisis dengan menggunakan mesin XRF desktop. 


\section{HASIL DAN PEMBAHASAN}

Sektor Lembah Hitam secara stratigrafi merupakan bagian atas dari Cekungan Kalan yang termasuk dalam seri atas. Secara umum litologi Sektor Lembah Hitam terdiri dari metapelit andalusit biotit (Jeronang Atas), metapelit andalusit (Jeronang Bawah), metalanau, metapelit, ampelit, metapelit sekistos (Gambar 6).

Metaampelit berwarna abu-abu kehitamanan, kadang kemerahan akibat alterasi. Batuan sangat kompak mengandung kuarsa, serisit, karbon, berukuran pelitik, pelamparan barat laut-tenggara sub vertikal $50^{\circ}-70^{\circ}$. Bidang sekistositas dan stratifikasi terlihat jelas, terdapat urat-urat kuarsa, pirit, pirhotit berukuran milimetrik sejajar dengan bidang sekistositas. Nilai radiometri sebesar 150 cps. Metalanau berwarna abu-abu-abu coklat, berukuran lanau, berkomposisi kuarsa, felspar, serisit, biotit, dengan nilai radiometri 150 cps. Batuan tersebut tersilisifikasi, terdapat urat mineralisasi $\mathrm{U}$ dengan nilai radioaktivitas 500-5.000 cps. Metapelit andalusit terdapat di bagian utara sektor yang merupakan lapisan teratas, berwarna abu-abu (segar), coklat kemerahan (lapuk), berbutir halus, mengandung banyak andalusit berbintik-bintik, dengan nilai radiometri 125 cps .

Stratifikasi merupakan struktur sisa perlapisan dari batuan yang telah mengalami proses metamorfosis. Pada daerah penelitian stratifikasi berarah timur laut-barat daya dengan kemiringan $40^{\circ}-70^{\circ}$ ke arah selatan. Kenampakan stratifikasi terlihat pada batuan inti bor (Gambar 7). Sekistositas merupakan struktur batuan metamorf pada daerah penelitian berarah barat laut-tenggara dengan kemiringan ke utara. Sesar yang ditemukan di lapangan, berdasarkan indikasinya secara umum, sejajar dengan orientasi arah timurbarat, berupa sesar mendatar dekstral berarah $\mathrm{N} 50^{\circ} \mathrm{E}$ (Gambar 6).

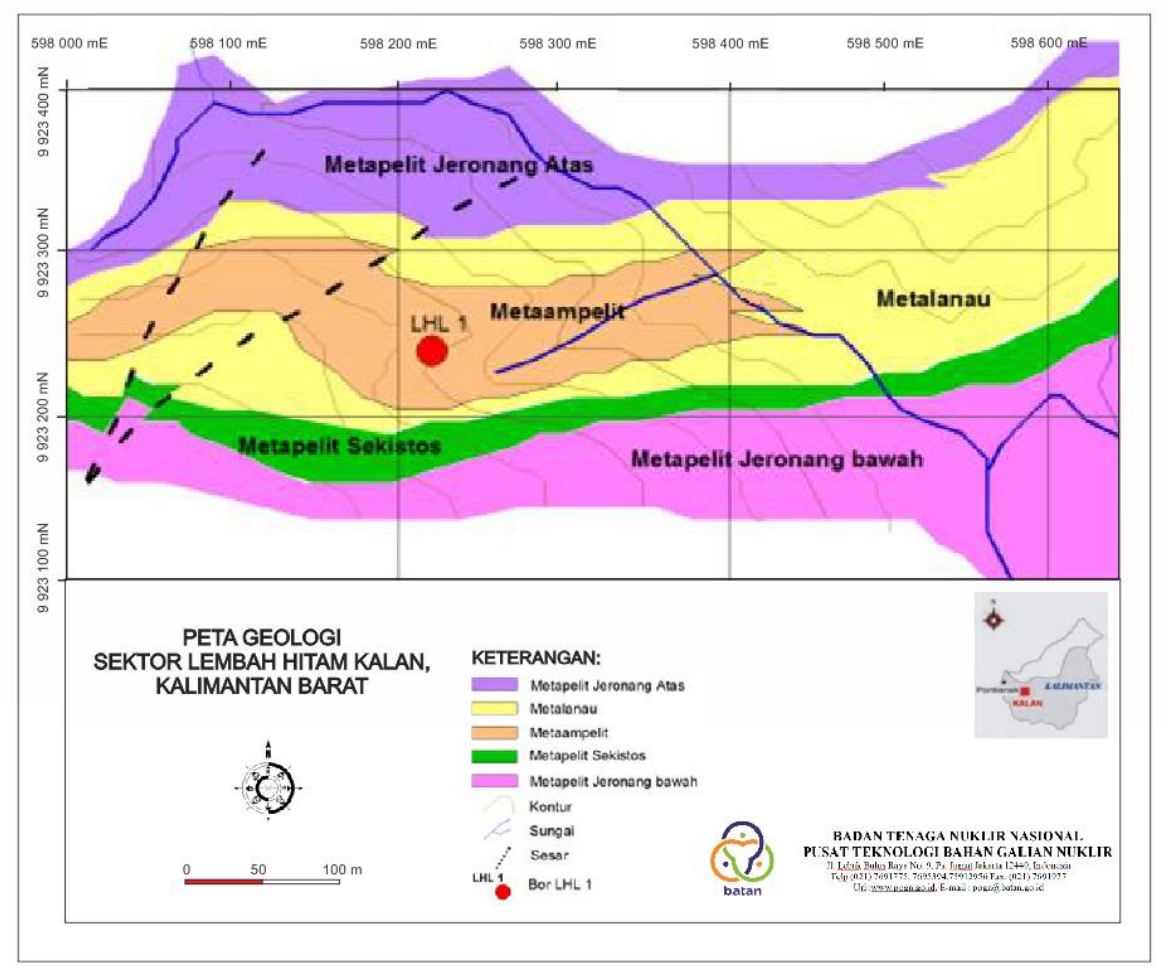

Gambar 6. Peta geologi Sektor Lembah Hitam, Kalan Kalimantan Barat. 

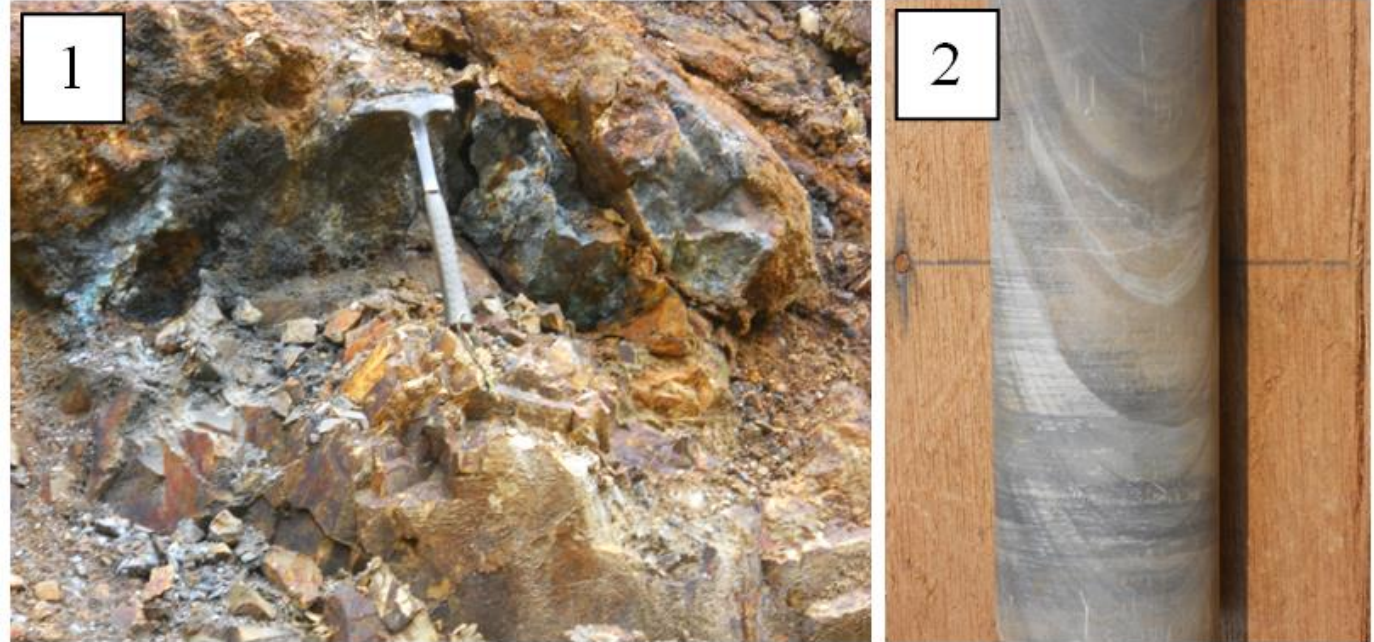

Gambar 7. Kenampakan stratifikasi pada singkapan (1) dan inti bor (2) metabatulanau.

Estimasi kadar secara kualitatif dengan menggunakan gross-count gamma ray pada sumur LH-01 dapat dilihat pada Tabel 1 dan 2. Hasil perhitungan log gross-count gamma ray pada sebaran batuan tersebut menunjukkan kandungan uranium berkisar antara $\quad 0,0261-0,1828 \quad \% \quad \mathrm{eU}_{3} \mathrm{O}_{8} . \quad$ Kadar uranium terendah ditemukan pada interval kedalaman 81,37-81,82 m, sementara kadar tertinggi pada interval kedalaman 65,01$65,29 \mathrm{~m}$.

Tabel 1. Hasil estimasi kadar secara kuatitatif dengan menggunakan gross count-gamma ray pada sumur LH-01.

\begin{tabular}{|c|c|c|c|c|c|c|c|c|c|c|c|}
\hline \multicolumn{2}{|c|}{ Kedalaman } & \multirow[b]{2}{*}{$\alpha$} & \multirow[b]{2}{*}{$\beta$} & \multirow{2}{*}{$\begin{array}{l}180- \\
(\alpha+\beta)\end{array}$} & \multirow{2}{*}{$\begin{array}{c}\text { Tebal } \\
\text { Semu } \\
\text { (LB) }\end{array}$} & \multirow{2}{*}{$\begin{array}{c}\text { Tebal } \\
\text { sebenarnya } \\
(\mathrm{Mw})\end{array}$} & \multirow{2}{*}{$\begin{array}{c}\text { Deadtime } \\
(\tau)\end{array}$} & \multirow{3}{*}{$\begin{array}{l}\text { Tail } \\
\text { Factor } \\
\text { (TF) }\end{array}$} & \multirow[b]{2}{*}{$\mathrm{E} 1+\mathrm{E} 2$} & \multirow[b]{2}{*}{$\Sigma \mathrm{N}$} & \multirow[b]{2}{*}[\mathrm{Ftx}(\mathrm{E}1+\mathrm{E}2)]{$+\Sigma \mathrm{N}$} \\
\hline Atas & Bawah & & & & & & & & & & \\
\hline$(\mathrm{m})$ & $(\mathrm{m})$ & (o) & (o) & (o) & $(\mathrm{m})$ & $(\mathrm{m})$ & (detik) & & (cps) & (cps) & (cps) \\
\hline 7 & 8,15 & 85,00 & 68 & 27,00 & 1,15 & 0,52 & 0,000005 & 0,91 & 536,77 & $5.380,18$ & $5.868,64$ \\
\hline 8,8 & 9,81 & 85,00 & 68 & 27,00 & 1,01 & 0,46 & 0,000005 & 0,91 & 599,00 & $5.155,66$ & $5.700,75$ \\
\hline 10,18 & 11,17 & 85,00 & 68 & 27,00 & 0,99 & 0,45 & 0,000005 & 0,91 & $1.014,57$ & $10.677,10$ & $11.600,36$ \\
\hline 12,32 & 13,32 & 85,00 & 68 & 27,00 & 1,00 & 0,45 & 0,000005 & 0,91 & $1.026,65$ & $12.450,03$ & $13.384,28$ \\
\hline 15,22 & 16,03 & 85,00 & 68 & 27,00 & 0,81 & 0,37 & 0,000005 & & & $25.012,75$ & \\
\hline 17,50 & 17,94 & 85,00 & 68 & 27,00 & 0,44 & 0,20 & 0,000005 & & & $3.919,55$ & \\
\hline 21,76 & 22,17 & 85,00 & 68 & 27,00 & 0,41 & 0,19 & 0,000005 & & & $1.169,07$ & \\
\hline 31,19 & 31,44 & 85,00 & 68 & 27,00 & 0,25 & 0,11 & 0,000005 & & & $2.917,37$ & \\
\hline 34,76 & 35,19 & 85,00 & 68 & 27,00 & 0,43 & 0,20 & 0,000005 & & & $6.434,24$ & \\
\hline 41,67 & 42,18 & 85,00 & 68 & 27,00 & 0,51 & 0,23 & 0,000005 & & & $2.447,53$ & \\
\hline 44,50 & 44,90 & 85,00 & 68 & 27,00 & 0,40 & 0,18 & 0,000005 & & & $1.573,82$ & \\
\hline 46,26 & 46,82 & 85,00 & 68 & 27,00 & 0,56 & 0,25 & 0,000005 & & & $7.198,78$ & \\
\hline 53,88 & 54,25 & 85,00 & 68 & 27,00 & 0,37 & 0,17 & 0,000005 & & & $2.234,11$ & \\
\hline 54,73 & 54,96 & 85,00 & 68 & 27,00 & 0,23 & 0,10 & 0,000005 & & & $3.302,18$ & \\
\hline 55,24 & 55,98 & 85,00 & 68 & 27,00 & 0,74 & 0,34 & 0,000005 & & & $3.015,39$ & \\
\hline 56,28 & 57,21 & 85,00 & 68 & 27,00 & 0,93 & 0,42 & 0,000005 & & & $15.540,72$ & \\
\hline 57,59 & 58,73 & 85,00 & 68 & 27,00 & 1,14 & 0,52 & 0,000005 & 0,91 & 777,51 & $7.660,86$ & $8.368,39$ \\
\hline 60,83 & 61,61 & 85,00 & 68 & 27,00 & 0,78 & 0,35 & 0,000005 & & & $4.969,58$ & \\
\hline 65,01 & 65,29 & 85,00 & 68 & 27,00 & 0,28 & 0,13 & 0,000005 & & & $6.981,91$ & \\
\hline 67,01 & 67,82 & 85,00 & 68 & 27,00 & 0,81 & 0,37 & 0,000005 & & & $3.870,49$ & \\
\hline 68,89 & 69,29 & 85,00 & 68 & 27,00 & 0,40 & 0,18 & 0,000005 & & & $4.614,39$ & \\
\hline 70,37 & 72,79 & 85,00 & 68 & 27,00 & 2,42 & 1,10 & 0,000005 & 0,91 & $2.621,19$ & $45.493,32$ & $4.7878,60$ \\
\hline 77,39 & 78,01 & 85,00 & 68 & 27,00 & 0,62 & 0,28 & 0,000005 & & & $2.806,31$ & \\
\hline 80,54 & 80,96 & 85,00 & 68 & 27,00 & 0,42 & 0,19 & 0,000005 & & & $1.845,40$ & \\
\hline 81,37 & 81,82 & 85,00 & 68 & 27,00 & 0,45 & 0,20 & 0,000005 & & & $1.601,75$ & \\
\hline 94,61 & 94,92 & 85,00 & 68 & 27,00 & 0,31 & 0,14 & 0,000005 & 0,91 & & $2.470,63$ & \\
\hline
\end{tabular}


Tabel 2. Hasil estimasi kadar secara kuatitatif dengan menggunakan gross-count gamma ray pada sumur LH-01 (lanjutan).

\begin{tabular}{|c|c|c|c|c|c|c|c|c|c|}
\hline \multicolumn{2}{|c|}{ Kedalaman } & \multirow{2}{*}{ Interval } & \multirow{2}{*}{ Area } & \multirow{3}{*}{$\begin{array}{l}\text { Casing } \\
\& \\
\text { faktor } \\
\text { lain } \\
\end{array}$} & \multirow{3}{*}{$\begin{array}{c}\text { Area } \\
\text { terkoreksi } \\
\text { (cps-m) } \\
\end{array}$} & \multirow{3}{*}{$\begin{array}{c}\text { K-Faktor (k) } \\
\text { (\% eU308/cps) }\end{array}$} & \multirow{3}{*}{$\begin{array}{c}\text { Rerata Grade } \\
\text { thickness }(\mathrm{G} \gamma \mathrm{T}) \\
(\% \text { eU308/m) }\end{array}$} & \multirow{3}{*}{$\begin{array}{c}G \gamma T=k A(\sin (\alpha+\beta)) \\
(G \gamma T \text { terkoreksi }) \\
(\% \text { eU3O8/m) }\end{array}$} & \multirow{3}{*}{$\begin{array}{c}\text { Rerata } \\
\text { Kadar }(\mathrm{G} \gamma) \\
\text { (\% eU308) } \\
\end{array}$} \\
\hline Atas & Bawah & & & & & & & & \\
\hline$(\mathrm{m})$ & $(\mathrm{m})$ & $(\mathrm{m})$ & (cps-m) & & & & & & \\
\hline 7 & 8,15 & 0,1 & 586,86 & 2,56 & $1.502,37$ & 0,00003721 & 0,0559 & 0,0254 & 0,0486 \\
\hline 8,8 & 9,81 & 0,1 & 570,07 & 2,56 & $1.459,39$ & 0,00003721 & 0,0543 & 0,0247 & 0,0538 \\
\hline 10,18 & 11,17 & 0,1 & $1.067,71$ & 2,56 & $2.733,34$ & 0,00003721 & 0,1017 & 0,0462 & 0,1027 \\
\hline 12,32 & 13,32 & 0,1 & $1.245,00$ & 2,56 & $3.187,21$ & 0,00003721 & 0,1186 & 0,0538 & 0,1186 \\
\hline 15,22 & 16,03 & 0,1 & $2.501,27$ & 2,56 & $6.403,26$ & 0,00003721 & 0,2383 & 0,1082 & 0,2942 \\
\hline 17,50 & 17,94 & 0,1 & 391,95 & 2,56 & $1.003,40$ & 0,00003721 & 0,0373 & 0,0170 & 0,0849 \\
\hline 21,76 & 22,17 & 0,1 & 116,91 & 2,56 & 299,28 & 0,00003721 & 0,0111 & 0,0051 & 0,0272 \\
\hline 31,19 & 31,44 & 0,1 & 291,74 & 2,56 & 746,85 & 0,00003721 & 0,0278 & 0,0126 & 0,1112 \\
\hline 34,76 & 35,19 & 0,1 & 643,42 & 2,56 & $1.647,17$ & 0,00003721 & 0,0613 & 0,0278 & 0,1425 \\
\hline 41,67 & 42,18 & 0,1 & 244,75 & 1,97 & 482,16 & 0,00003721 & 0,0179 & 0,0081 & 0,0352 \\
\hline 44,50 & 44,90 & 0,1 & 157,38 & 1,97 & 310,04 & 0,00003721 & 0,0115 & 0,0052 & 0,0288 \\
\hline 46,26 & 46,82 & 0,1 & 719,88 & 1,97 & $1.418,16$ & 0,00003721 & 0,0528 & 0,0240 & 0,0942 \\
\hline 53,88 & 54,25 & 0,1 & 223,41 & 1,97 & 440,12 & 0,00003721 & 0,0164 & 0,0074 & 0,0443 \\
\hline 54,73 & 54,96 & 0,1 & 330,22 & 1,97 & 650,53 & 0,00003721 & 0,0242 & 0,0110 & 0,1052 \\
\hline 55,24 & 55,98 & 0,1 & 301,54 & 1,97 & 594,03 & 0,00003721 & 0,0221 & 0,0100 & 0,0299 \\
\hline 56,28 & 57,21 & 0,1 & $1.554,07$ & 1,97 & $3.061,52$ & 0,00003721 & 0,1139 & 0,0517 & 0,1225 \\
\hline 57,59 & 58,73 & 0,1 & 836,84 & 1,97 & $1.648,57$ & 0,00003721 & 0,0613 & 0,0278 & 0,0538 \\
\hline 60,83 & 61,61 & 0,1 & 496,96 & 1,97 & 979,01 & 0,00003721 & 0,0364 & 0,0165 & 0,0467 \\
\hline 65,01 & 65,29 & 0,1 & 698,19 & 1,97 & $1.375,44$ & 0,00003721 & 0,0512 & 0,0232 & 0,1828 \\
\hline 67,01 & 67,82 & 0,1 & 387,05 & 1,97 & 762,49 & 0,00003721 & 0,0284 & 0,0129 & 0,0350 \\
\hline 68,89 & 69,29 & 0,1 & 461,44 & 1,97 & 909,04 & 0,00003721 & 0,0338 & 0,0154 & 0,0846 \\
\hline 70,37 & 72,79 & 0,1 & $4.787,86$ & 1,97 & $9.432,08$ & 0,00003721 & 0,3510 & 0,1593 & 0,1450 \\
\hline 77,39 & 78,01 & 0,1 & 280,63 & 1,97 & 552,84 & 0,00003721 & 0,0206 & 0,0093 & 0,0332 \\
\hline 80,54 & 80,96 & 0,1 & 184,54 & 1,97 & 363,54 & 0,00003721 & 0,0135 & 0,0061 & 0,0322 \\
\hline 81,37 & 81,82 & 0,1 & 160,17 & 1,97 & 315,54 & 0,00003721 & 0,0117 & 0,0053 & 0,0261 \\
\hline 94,61 & 94,92 & 0,1 & 247,06 & 1,97 & 486,71 & 0,00003721 & 0,0181 & 0,0082 & 0,0584 \\
\hline
\end{tabular}

Korelasi Antara Data Logging dengan Inti Batuan

Dari hasil korelasi antara data inti bor dengan data logging, maka telah dipilih sampel dari inti bor LH-01 pada kedalaman yang dianggap mewakili Sektor Lembah Hitam. Berdasarkan hasil pengamatan serta mempertimbangkan kemunculan zona mineralisasi di dalam batuan inti bor dan dalam gross count gamma ray, maka dipilih sampel yang dianggap mewakili yaitu pada interval kedalaman 8,80-9,81 m (Tabel 3). Batuan inti bor yang terambil kemudian diukur nilai radiometrinya dengan menggunakan sintilometer SPP2NF dan dianalisis menggunakan metode XRF. Nilai radiometri yang terukur berkisar antara 60375 cps. Sementara itu, hasil analisis XRF menunjukkan nilai kadar berkisar antara 25,4-805,5 ppm U. Hasil respon log gamma dan pengukuran radiometri sampel pada interval $8,80-9,81 \mathrm{~m}$ memiliki pola yang relatif sama walau intensitasnya berbeda. Hal ini bisa terjadi karena secara umum deposit $\mathrm{U}$ bersifat nuggety.

Hasil analisis geokimia dengan menggunakan XRF terhadap sebelas sampel dan korelasinya dengan gross-count gamma ray dapat dilihat pada Gambar 8. 
Tabel 3. Penentuan interval sampel inti bor yang akan dianalisis berdasarkan log gamma dan korelasinya dengan pengukuran SPP2NF.

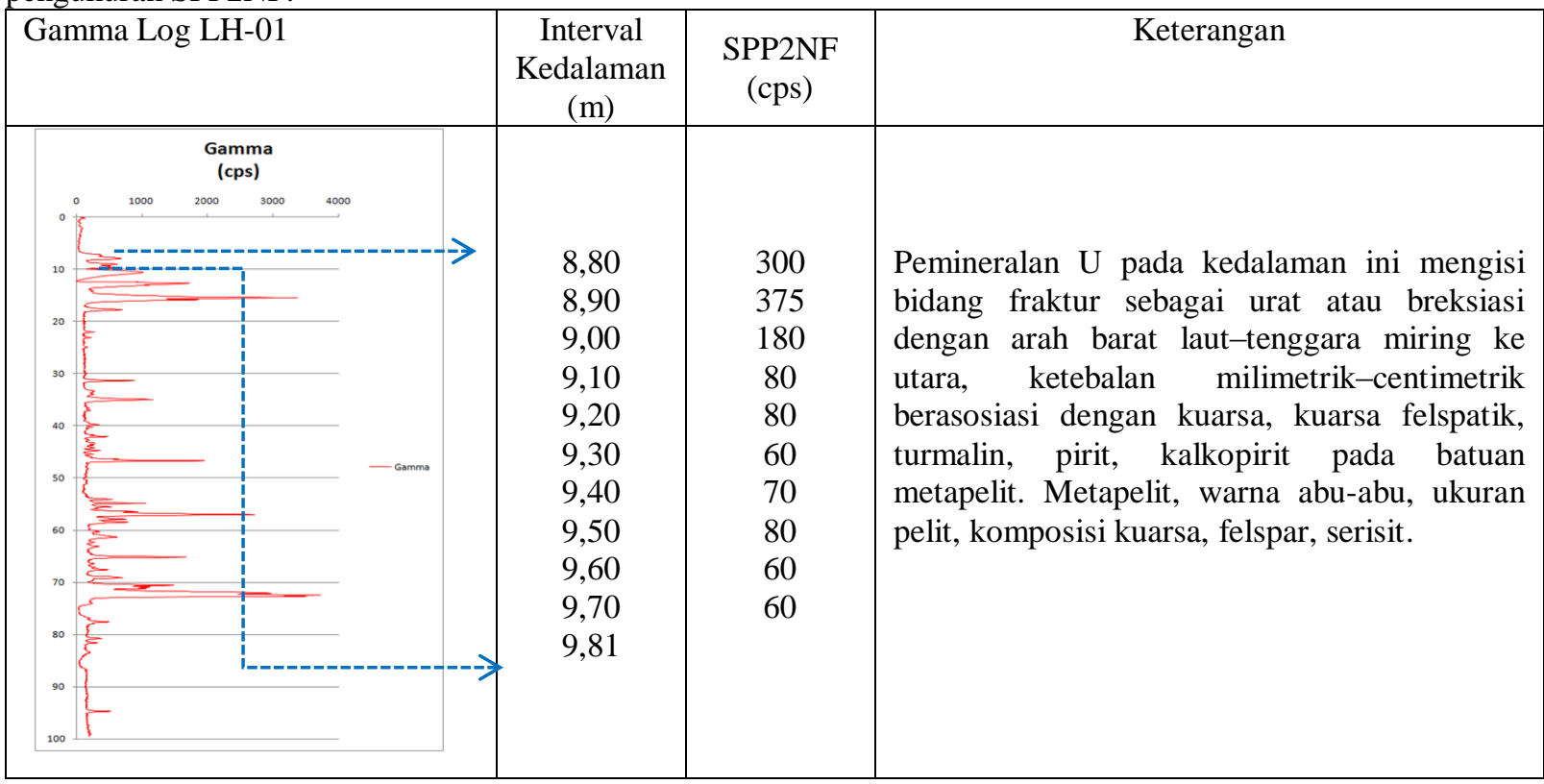

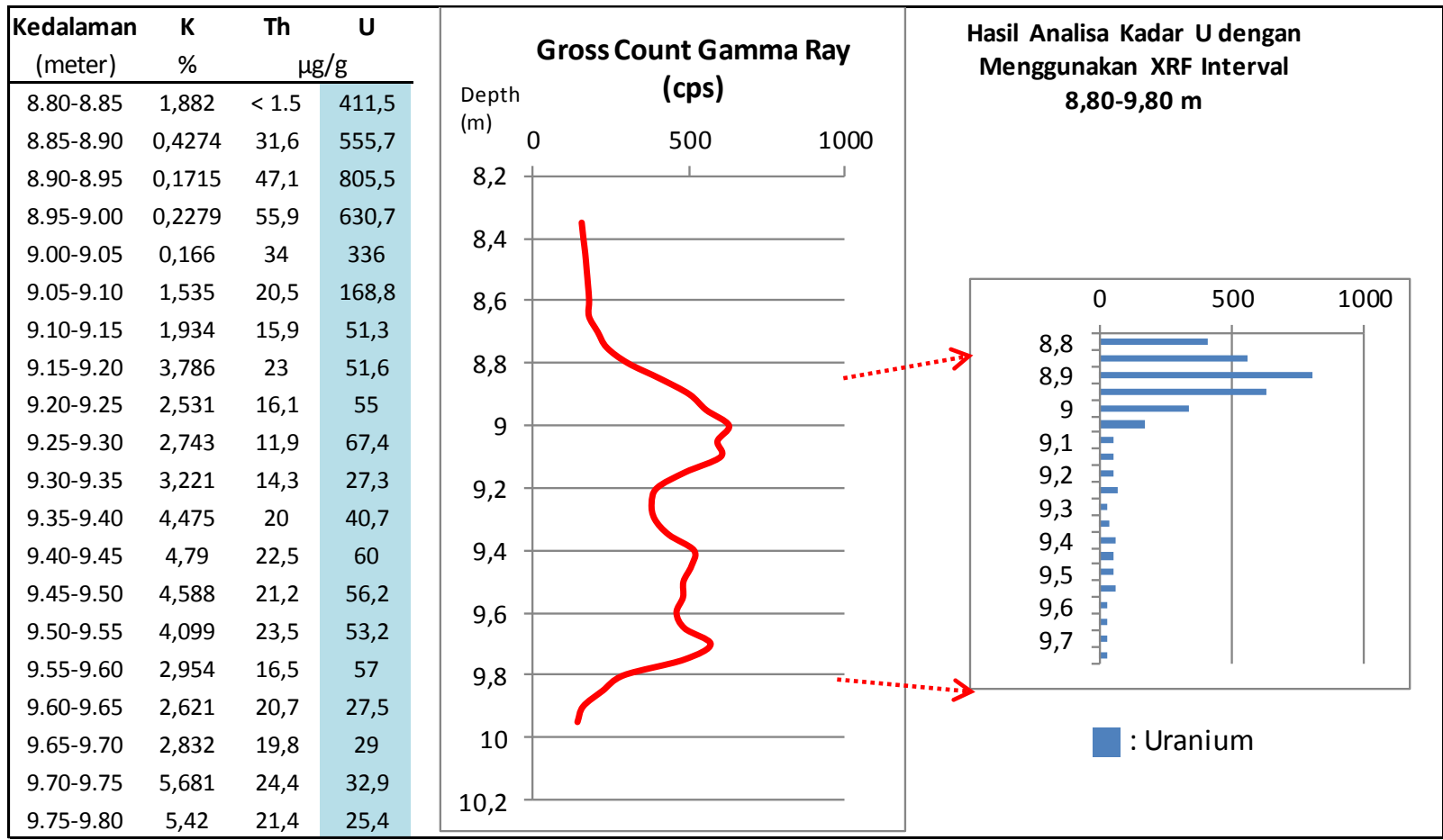

Gambar 8. Hasil analisis geokimia interval 8,80-9,80 $\mathrm{m}$ dengan menggunakan XRF dan korelasinya dengan data gross-count gamma ray.

Hasil estimasi kadar menggunakan logging dengan mengacu pada prinsip dasar logging gross-count gamma ray, didapatkan kadar rata-rata mineralisasi pada interval 8,80-9,81 meter sebesar 0,0538 \% eU $\mathrm{eU}_{3} \mathrm{O}_{8}$ atau ekivalen dengan $456 \mathrm{ppm}$ eU. Sementara hasil analisis XRF pada kedalaman 8,80-9,81 meter didapatkan nilai rata-rata kadar yang berbeda walaupun dengan pola distribusi yang relatif sama, sebesar 177 ppm U (Gambar 8). Hal ini bisa terjadi karena pemilihan sampel yang tidak akurat ataupun 
faktor lain. Ada beberapa faktor yang menyebabkan terjadinya perbedaan antara data estimasi kadar dengan menggunakan gross-count gamma ray dengan hasil analisis geokimia. Faktor-faktor tersebut antara lain: sistem pada logging gross-count gamma ray, ketidaksetimbangan uranium, perbedaan ukuran sampel, dan keberadaan unsur radioaktif lainnya.

Dengan menggunakan data sampel pada kedalaman ini, 8,80-9,81 meter, didapatkan faktor koreksi sebesar:

$$
F_{k}=\frac{177,135}{456}=0,388454
$$

Nilai $F_{k}$ sebesar 0,388454 didapatkan dari pengukuran pada 20 sampel di interval kedalaman 8,80-9,81 m. Nilai ini masih sangat jauh dari nilai Fk yang ideal, yaitu mendekati 1. Sebagai perbandingan, studi penentuan kadar U secara laboratorium dengan menggunakan log gross-count gamma ray terhadap 39 sampel di Grand Junction Colorado menunjukkan rata-rata perbedaanya sebesar $\pm 3,2 \%$ atau 0,032 [22] . Beberapa faktor yang dapat mempengaruhi hasil pembacaan logging gross-count gamma ray antara lain: faktor koreksi sistem logging (death time), kondisi lubang bor (diameter lubang bor, air, casing), dan kondisi ketidaksetimbangan formasi (disequilibrium) [2]. Kecuali kondisi ketidaksetimbangan formasi, faktor koreksi sistem logging (death time), kondisi lubang bor (diameter lubang bor/air, casing) sudah diplikasikan di dalam penaksiran kadar $\mathrm{U}$ dengan menggunakan logging gross-count gamma ray ini, sehingga didapatkan hasil seperti pada Tabel 1.

Ketidaksetimbangan uranium merupakan salah satu faktor terjadinya perbedaan antara hasil penentuan kadar dari logging sumur bor dengan data analisis geokimia. Gamma ray yang tercatat oleh sistem logging gross-count gamma ray berasal dari produk turunan uranium, yaitu ${ }^{214} \mathrm{~Pb}$ dan ${ }^{214} \mathrm{Bi}$ bukan berasal dari $U$, karena $U$ tidak memancarkan sinar gamma tapi alfa. Kesetimbangan kimia $\mathrm{U}$ dapat terganggu diakibatkan oleh adanya air meteorik, sehingga sebagian $U$ yang terendapkan berpindah ke suatu tempat dan yang tertinggal hanya produk peluruhannya ${ }^{214} \mathrm{Bi}$ dan ${ }^{214} \mathrm{~Pb}$. Kondisi ini bisa memberikan false anomaly terhadap pembacaan gamma ray dalam sistem logging gross-count gamma ray, sehingga hasil penaksiran kadar dengan logging ini menjadi tidak akurat. Ketidaksetimbangan dapat menyebabkan pengambilan sampel menjadi tidak akurat dan tidak presisi. Ilustrasi akurat dan presisi sampel bisa dilihat pada Gambar 9. Sebagai catatan, sampel logging dengan sampel geokimia merupakan 2 sampel yang berbeda, sehingga apabila terjadi perbedaan bisa jadi karena pemilihan sampel yang tidak akurat dan tidak presisi.

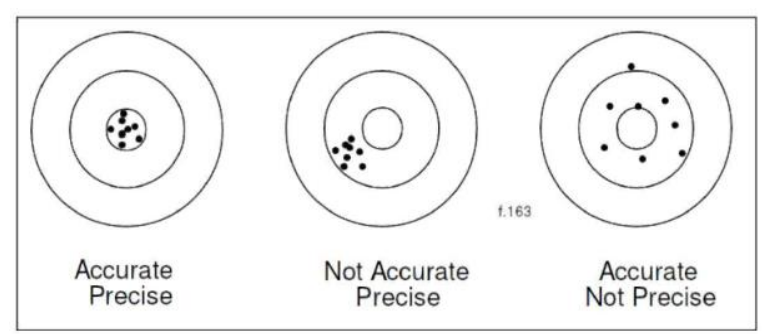

Gambar 9. Ilustrasi tingkat akurasi dan presisi di dalam pengambilan sampel.

Dalam hal perbedaan ukuran sampel antara sampel batuan inti bor untuk analisis geokimia dengan sampel logging, ukuran sampel untuk logging bisa berkuran 100 kali lebih besar jika dibanding sampel untuk analisis geokimia disamping dan merupakan dua sampel yang berbeda. Sebagai catatan, apabila ada perbedaan hasil maka yang harus 
selalu diingat adalah sifat dari deposit uranium yang heterogen dan nuggety. Hasil analisis geokimia menunjukkan keberadaan unsur radioaktif Th dan produk turunannya. Dalam estimasi kadar menggunakan gross count gamma ray, keberadaan torium dan unsur radioaktif yang lain diabaikan, sehingga apabila ada Th dijumpai bersamaan dengan $U$ akan meninggikan hasil pembacaan $\log$ gross-count gamma ray.

Berdasarkan hal tersebut, sebanyak 20 sampel dari satu zona mineralisasi belumlah cukup untuk memberikan gambaran keseluruhan tentang validitas dan reliabilitas data penghitungan kadar. Perlu dilakukan pengambilan sampel lebih banyak lagi, sehingga bisa dicari hubungan antara kadar ekivalen yang didapatkan dari data logging dengan kadar $U$ yang didapatkan dari data geokimia. Nilai ini nantinya dipakai sebagai faktor koreksi terhadap hasil estimasi sumberdaya. Jumlah sampel saat ini masih terlalu sedikit untuk bisa mewakili kondisi yang ada di Sektor Lembah Hitam, sehingga belum bisa ditentukan seberapa besar nilai penyimpangannya.

\section{KESIMPULAN}

Dari hasil kesebandingan antara hasil estimasi kadar dengan menggunakan log gross-count gamma ray dengan analisis geokimia dengan menggunakan XRF terdapat perbedaan yang cukup signifikan antara hasil ekivalen kadar dengan penentuan kadar dengan menggunakan XRF. Kadar rata-rata mineralisasi pada interval $8,80-9,81$ meter sebesar $0,0538 \quad \% \quad \mathrm{eU}_{3} \mathrm{O}_{8}$ atau ekivalen dengan $456 \mathrm{ppm} \mathrm{U}$, sedangkan pada kedalaman yang sama dengan menggunakan XRF didapatkan kadar rata-rata sebesar 177 ppm. Menggunakan data sampel pada kedalaman 8,80-9,81 meter maka didapatkan Faktor Koreksi $\left(\mathrm{F}_{\mathrm{k}}\right)$ sebesar 0,388. Ada beberapa faktor yang menyebabkan terjadinya perbedaan antara data estimasi kadar dengan menggunakan gross-count gamma ray dengan hasil analisis geokimia yaitu faktor koreksi sistem logging gross-count gamma ray, faktor ketidaksetimbangan uranium, perbedaan ukuran sampel, keberadaan unsur radioaktif yang lain seperti Th, yang memepengaruhi hasil pembacaan gross-count gamma ray.

\section{SARAN}

Perlu dilakukan pengambilan sampel lebih banyak lagi, sehingga bisa dicari hubungan antara kadar ekivalen yang didapatkan dari data logging gross-count gamma ray dengan kadar U yang didapatkan dari data geokimia.

\section{UCAPAN TERIMA KASIH}

Penulis mengucapkan terima kasih kepada Kepala Bidang Eksplorasi dan Kepala Pusat Teknologi Bahan Galian Nuklir untuk kesempatan yang diberikan dalam melakukan penelitian ini.

\section{DAFTAR PUSTAKA}

[1] S. Tjokrokardono, D. Soetarno, M. S. Sapardi, L. Subiantoro, and R. Witjahyati, "Studi Geologi Regional dan Mineralisasi Uranium di Pegunungan Schwanner Kalimantan Barat dan Tengah," in Prosiding Seminar Geologi Nuklir dan Sumberdaya Tambang, 2004, pp. 64-84.

[2] IAEA, Technical Reports Series No.212: Borehole Logging for Uranium Exploration, A Manual. Vienna: International Atomic Energy Agency, 1982

[3] P. R. Williams, C. R. Johnston, R. A. Almond, and W. H. Simamora, "Late Cretaceous to Early Tertiary Structural Elements of West Kalimantan," Tectonophysics, vol. 148, no. 3-4, pp. 279-297, 1988 .

[4] G. A. F. Molengraaff, Borneo-expedition. Geological Explorations in Central Borneo (1893-94) by Dr GAF Molengraaff, Enf Rev Ed. 1902.

[5] Amiruddin and D. S. Trail, "Peta Geologi Lembar Nanga Pinoh Kalimantan Skala 1: 250.000," Bandung, 1993.

[6] S. Papeschi, G. Musumeci, and F. Mazzarini, 
"Heterogeneous Brittle-Ductile Deformation at Shallow Ccrustal Levels Under High Thermal Conditions: The Case of a Synkinematic Contact Aureole in Theinner Northern Apennines, Southeastern Elba Island, Italy," Tectonophysics, vol. 717, pp. 547-567, 2017.

[7] Ngadenin, F. D. Indrastomo, K. S. Widana, and Widodo, "Identifikasi Keterdapatan Mineral Radioaktif pada Urat-Urat Magnetit di Daerah Ella Ilir , Melawi , Kalimantan Barat," Eksplorium, vol. 40, no. 1, pp. 33-42, 2019.

[8] H. S. Karyono and M. Ruhland, "Use of Multiscalar Processing of Remotely Sensed Data in Kalan Fracturation Networks West Kalimantan, Indonesie for Future Mineralization Research," ISPRS J. Photogrametry Remote Sens., vol. 45, pp. 428-441, 1990.

[9] A. S. Sastratenaya, "Deformation et Mobilite Megaprisme Tectonique De Pinoh-Sayan, Kalimantan, Indonesie," These Docteur, L'Universite Louis Pasteur De Strassbourg, France, 1991.

[10] S. Tjokrokardono, L. Subiantoro, and M. Widodo, "Sintesis Geologi dan Mineralisasi Uranium Kalan dan Sekitarnya, Kalimantan Barat," 2006.

[11] S. Tjokrokardono, "Prospek Pengembangan Cebakan Uranium di Kalan, Kalimantan," $J$. Nukl. Indones., vol. 1, pp. 1-12, 1998.

[12] BATAN-CEA, Prospect to Develop Uranium Deposits in Kalimantan Volume I and II, Introduction General Reconnaissance. 1977.

[13] R. B. Tate, "Cross-border Correlation of Geological Formations in Sarawak and Kalimantan," Bull. Geol. Soc. Malaysia, vol. 28, pp. 63-96, 1991.

[14] P. E. Pieters and Sanyoto, "Peta Geologi Lembar Pontianak/Nangataman, Kalimantan Skala 1:250.000," Bandung, 1993.

[15] L. B. Davies, R. Hall, and R. Amstrong, "Cretaceous Crust in SW Borneo: Petrological, Geochemical and Geochronological Constraints from the Schwaner Mountains," in Proceedings
Indonesian Petroleum Association, 38th Annual Convention and Exhibition, 2014, p. IPA14-G025.

[16] L. B. Davies, SW Borneo Basement: Age, origin and character of igneous and metamorphic rocks from the Schwaner Mountains. London: Royal Holloway University of London, 2013.

[17] N. I. Setiawan, Y. Osanai, N. Nakano, T. Adachi, K. Yonemura, A. Yoshimoto, J. Wahyudiono, and K. Mamma, "An Overview of Metamorphic Geology from Central Indonesia: Importance of South Sulawesi, Central Java and South-West Kalimantan Metamorphic Terranes," Bull. Grad. Sch. Soc. Cult. Stud. Kyushu Univ., vol. 19, pp. 39-55, 2013.

[18] N. I. Setiawan, Y. Osanai, N. Nakano, T. Adachi, L. D. Setiadji, and J. Wahyudiono, "Late Triassic Metatonalite from the Schwaner Mountains in West Kalimantan and its contribution to Sedimentary Provenance in the Sundaland," Ber. Sedimentol., vol. 12, no. 28, pp. 4-12, 2013.

[19] H. T. Breitfeld, R. Hall, T. Galin, M. A. Forster, and M. K. BouDagher-Fadel, "A Triassic to Cretaceous Sundaland-Pacific Subduction Margin in West Sarawak, Borneo," Tectonophysics, vol. 694, pp. 35-56, 2017.

[20] S. Tjokrokardono and A. S. Sastratenaya, "Rich Mineralized Boulders of the Rirang River, West Kalimantan.," in Proceeding of Technical Committe Meeting on Uranium Deposits in Asia and the Pacific: Geology and Exploration, 1988.

[21] J. Pablo, R. Lozano, and J. P. Bernal, "Characterization of A New Set of Eight Geochemical Reference Materials for XRF Major and Trace Element Analysis," Rev. Mex. Ciencias Geológicas, vol. 22, no. 3, pp. 329-344, 2005.

[22] D. C. George, B. E. Heistand, and J. E. Krabacher, "Grade Assignments for Models Used for Calibration of Gross-Count Gamma-Ray Logging Systems." U.S. Dept. of Energy Asistant Secretary for Nuclear Energy, Colorado, p. 62, 1983. 